\title{
Farming with trees on sand country
}

\section{Denis Hocking \\ Farmer, Bulls}

My account does not rely on quantitative data, which is limited, but it instead outlines my land use strategies on a coastal sand country property.

\section{BACKGROUND}

The property has been owned and operated by a collection of family members for 34 years, having been brought with a keen eye for its forestry potential. My father was in the New Zealand Forest Service, and was a keen advocate of farm forestry. Thus the property has been developed as a sheep and cattle and also as a forestry operation, with production forestry being concentrated on the Foxton and Motuiti soils, i.e., the dunes, along with shelter and woodlot/shelter plantings on the flats. Recently a further 80 ha have been added with the same objectives in mind.

\section{THE PROPERTY TODAY}

The property I have farmed for the past 13 years is 160 ha of sand country in the older sand associations at the inland end of the Rangitikei coastal sand country. The soil types are roughly $40 \%$ Foxton and Motuiti sand dunes (potential carrying capacity 3-5 su/ha), 35\% Himatangi dry sand flats (potential carrying capacity 10-12 su/ha), $12 \%$ Carnarvon and Puki-puki wet sands and $12 \%$ Ohakea clays (all of which have a carrying capacity of around $20 \mathrm{su} / \mathrm{ha}$ ). The property is now roughly one third production forestry plantations with 1500 stock units split roughly 2:1 sheep:cattle and a few goats.

As the property is on predominantly light sand soils, it is prone to summer/autumn droughts, but with characteristic sand country spring and autumn flushes of annual clovers. Everything tends to happen in a bit of a hurry.

Rainfall, at about $800 \mathrm{~mm}$, should be adequate, but tends to be erratic. A high wind run, with a saline westerly, further compounds problems. However, soil nutrient levels on the flats and easier dunes are quite good, as shown by soil test. However, the steeper dunes have been fertilised only very occasionally.

Attempts to better utilise the flats have concentrated on increased subdivision with electric fencing (permanent and temporary), controlled grazing and the use of some of the newer pasture cultivars. Increased shelter plantings have probably been hindered by my desire to break away from the monotony of radiata pine.

\section{STOCK PERFORMANCE}

Animal performance is adequate but not outstanding under these conditions of dry summers. Early prime lamb production used to be the favoured option, but I am now breeding replacements only. Lambing percentages have been in the range of $120-130 \%$ in recent years, wool production about $5 \mathrm{~kg} / \mathrm{su}$. Cattle performance is somewhat better, with three way crossing enabling 6-7 month weaning weights to average around $270-290 \mathrm{~kg}$.

\section{PASTURES}

On the light sands, three of the newer Grassland cultivars have looked very impressive, though I hasten to add that I have no quantitative data.

Matua prairie grass, in mixtures or on its own, looks impressive for the first one or two seasons in the winter but fades thereafter. It may decline because of overgrazing, especially during the spring when Matua is less competitive, but I wonder whether Matua might not age, physiologically, rather faster than most perennials, and lose vigour. Remaining plants in older stands do not seem to have anything like the vigour of young stands. Refer to papers elsewhere in proceedings.

Wana cocksfoot has the advantage of being competitive and persistent, though slow to establish, on the sands. However, its drought tolerance is insufficient to withstand sand country summers and it bums off in summer and autumn dry spells. Maru phalaris, with its winter vigour, summer dormancy and opportunistic growth habit, is admirably suited to sand country, but seems to prefer pure stands rather than mixtures. It is a cultivar I intend to use more extensively.

The clovers are dominated by Mt Barker subterranean clover, with some of the suckling clover also being prominent. A flush of very cloverdominant pasture from mid September to mid November is also a sand country trademark. Unfortunately, white clovers have not survived well to date. Tahora looks the most likely, but the sands tend to bum off in late November before the white clovers have set seed. 
On all these light soils, ratstail, Indian doab, buffalo grass and poa species are always poised to reclaim the land.

\section{FORESTRY}

In recent years the forestry operation has tended to carry the property. About $36 \%$ of the property is now in production forestry, with the oldest plantings dating back to the late 1950 s, early 1960 s.

Planting of straight radiata pine stands would normally be at 400-600 stems per ha (sph), unless weed problems necessitate higher densities. Widespaced agroforestry plantings have been tried but seem a dubious exercise on this class of land. Time and effort needed to provide protection for the trees probably exceeds the value of the grazing.

Thinning for posts has been dispensed with, being a cost rather than a credit. Instead, from age 14-17 years I start 'milking' these stands for saw logs, thinning about 100 trees per ha at a time on a $2-4$ years cycle. The aim is for a final crop of about 100 $\mathrm{sph}$, with trees being grown through to $70-80 \mathrm{~cm}$ diameter at breast height, perhaps larger, on a 30-35 year rotation. Currently I have one 26-year-old stand at $100 \mathrm{sph}$ that is gaining about $\$ 2000 / \mathrm{ha} /$ year in gross timber value.

Such an approach has suited me well, allowing effective utilisation of land that has little stock carrying potential. The intermediate cash flow has been invaluable over the past 5 years, and has worked out at about $\$ 1000 / \mathrm{ha} /$ year for plantations in the production thinning stage. I have been grossing $\$ 20,000-\$ 30,000$ per year from production thinning, with the most valuable part of the rotation, the final crop, as yet untouched.

\section{Grazing of stands}

Meanwhile, grazing of the stands has been continued, though at reduced levels.
In the first 8-10 years, with the trees being pruned regularly and thus having light crowns, production seemed little affected. The stands are treated as extra paddocks for the ewe rotation. In the older stands I have had considerable success establishing white clover on Himatangi and even Foxton/ Motuiti soils -something that does not happen in the open - but it appears to be too dry for Maku lotus.

Cocksfoot is, without doubt, the agroforestry grass of choice, handling shade and dry conditions very well. Unfortunately, poa and Indian doab tend to be the species of chance.

Regardless of the species present, it appears that shaded pasture is less palatable than unshaded pasture. Shaded pasture also shows a different growth habit, hanging on better in summer, but lacking the spring and autumn flushes.

\section{Goats}

Goats have been introduced into several older stands, once the rougher adult bark has appeared at $10-12$ years. They seem to handle conditions well and do an excellent job of keeping the stands clear of most weeds, especially blackberry. In addition they help the breakdown of thinning slash by eating bark and needles.

\section{Alternative trees}

A variety of alternative species have been tried, including cypresses, eucalypts and acacias, but in my more honest moments I would have to admit that while alternative species may be more fun, few look like commercial propositions on dry, nitrogendeficient sands in the face of saline winds. 